\title{
Accessory axillary breasts versus axillary tumours: diagnostic challenge
}

\author{
Masaki Tago, ${ }^{\circledR}$ Naoko E Katsuki, Shu-ichi Yamashita
}

Department of General Medicine, Saga University Hospital, Saga, Japan

Correspondence to Dr Masaki Tago, tagomas@cc.saga-u.ac.jp

Accepted 29 August 2019

\section{DESCRIPTION}

A 38-year-old woman with no medical history noticed swellings in both axillary regions 9 months previously. She visited another hospital because she had a slight fever and axillary discomfort due to gradual growth of the swellings during the last 3 months. She had no history of weight loss, appetite loss, nocturnal sweating, pregnancy or variation in the size of the swellings with her menstrual cycle. On the first visit to other breast surgery clinic, laboratory examinations revealed no abnormalities; inflammatory responses and antinuclear antibody were negative, and thyroid function was normal. Mammography and breast ultrasonography performed at the clinic revealed no abnormalities in her normally positioned breasts without detecting accessory axillary breast tissues. She was then referred to our department for a thorough examination. Physical examination did not show any abnormalities in normally positioned breast tissues or systemic lymphadenopathy. Soft and poorly marginated elevated lesions without tenderness were present in both anterior axillary areas, which were difficult to detect as masses on palpation (figure 1). Ultrasonography of the axillary areas revealed heterotopic, apparently normal breast structures (figure 2). MRI of the left axillary area also showed a normal breast structure without any abnormalities characteristic of tumours or inflammatory diseases (figure 3). The patient was consequently diagnosed with accessory axillary breasts.

The incidence of supernumerary or accessory breasts is reportedly about $1 \%$ and $5 \%$ in men and women respectively, which is lower than those

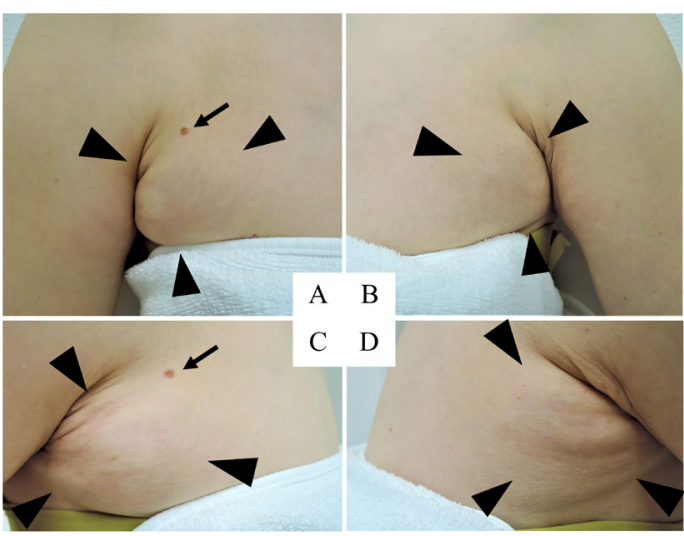

Figure 1 Findings of both anterior axillary areas. (A-D) Soft and poorly marginated elevated lesions are present in both anterior axillary areas, which were difficult to detect as masses on palpation (arrowheads). (A, C) An accessory nipple is present on the right side (arrows).

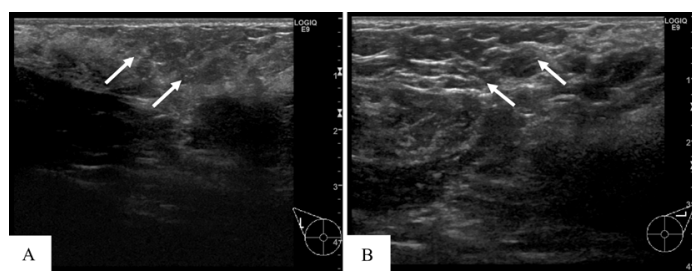

Figure 2 Ultrasonography of the both axillary areas. (A) Right side, (B) Left side. (A, B) Ultrasonography of both sides of anterior axillary areas revealed heterotopic, but apparently normal breast structures (arrows).

of supernumerary or accessory nipples. ${ }^{1}$ Supernumerary breast tissues are usually found along the milk lines extending from the axilla to pubic region. ${ }^{2}$ Some cases of accessory breasts were pathologically diagnosed after surgical resection; they had been suspected to be lipomas because of their increase in size over time. ${ }^{3}$ Pathological changes such as mastitis, fibrocystic disease, or even carcinoma, which is rare, can occur in accessory breasts even in the presence of normal histological breast structures. ${ }^{4}$

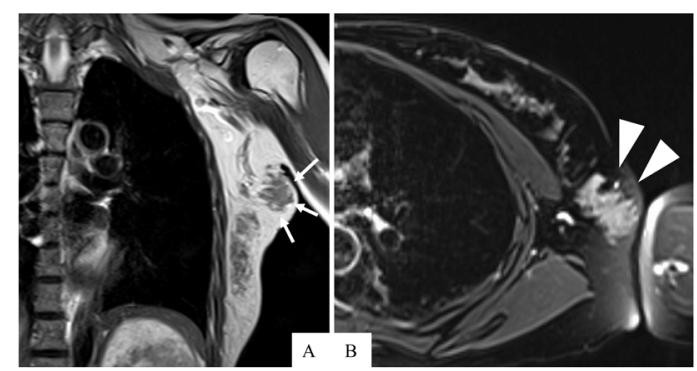

Figure 3 MRI of left axillary area. (A) Coronal view of $\mathrm{T2}$-weighted image reveals an isodense lesion in the left axillary area, and its appearance is similar to that of normal breast structure (arrows). (B) Axial view of T2-weighted and fat-suppressed image reveals highdensity lesion (arrowheads), which is compatible with the findings of accessory breast tissue.

Learning points

- Accessory axillary breasts are uncommon and can often be a diagnostic challenge.

- Carcinoma can occur in accessory axillary breasts, though such case is rather rare.

- Some cases of accessory breasts were pathologically diagnosed after surgical resection; they had been initially suspected to be lipomas. 
Clinicians should be alert to accessory breasts in patients with soft and poorly marginated elevated lesions in the axillary areas. Such patients, especially 40 years old or older, might require periodic check-ups for breast cancer in accessory axillary breasts by ultrasonography despite the fact that such cancer development is rather rare. ${ }^{5}$

Acknowledgements The authors thank Angela Morben, DVM, ELS, from Edanz Group (www.edanzediting.com/ac), for editing a draft of this manuscript.

Contributors MT: involved in literature search, concept, drafting and clinical care of the patient. NEK: involved in literature search, concept and drafting. S-IY: involved in concept and revision of article.

Funding The authors have not declared a specific grant for this research from any funding agency in the public, commercial or not-for-profit sectors.
Competing interests None declared.

Patient consent for publication Obtained.

Provenance and peer review Not commissioned; externally peer reviewed.

\section{REFERENCES}

1 Dixon JM, Mansel RE. ABC of breast diseases. Congenital problems and aberrations of normal breast development and involution. BMJ 1994;309:797-800.

2 Grossl NA. Supernumerary breast tissue: historical perspectives and clinical features. South Med J 2000;93:29-32.

3 Husain M, Khan S, Bhat A, et al. Accessory breast tissue mimicking pedunculated lipoma. BMJ Case Rep 2014;2014:bcr2014204990.

4 Khanna S, Mishra SP, Kumar S, et al. Carcinoma in accessory axillary breast. BMJ Case Rep 2015;2015:bcr2015210944.

5 Nihon-Yanagi Y, Ueda T, Kameda N, et al. A case of ectopic breast cancer with a literature review. Surg Oncol 2011;20:35-42.

Copyright 2019 BMJ Publishing Group. All rights reserved. For permission to reuse any of this content visit

https://www.bmj.com/company/products-services/rights-and-licensing/permissions/

BMJ Case Report Fellows may re-use this article for personal use and teaching without any further permission.

Become a Fellow of BMJ Case Reports today and you can:

- Submit as many cases as you like

- Enjoy fast sympathetic peer review and rapid publication of accepted articles

- Access all the published articles

- Re-use any of the published material for personal use and teaching without further permission

\section{Customer Service}

If you have any further queries about your subscription, please contact our customer services team on +44 (0) 2071111105 or via email at support@bmj.com.

Visit casereports.bmj.com for more articles like this and to become a Fellow 